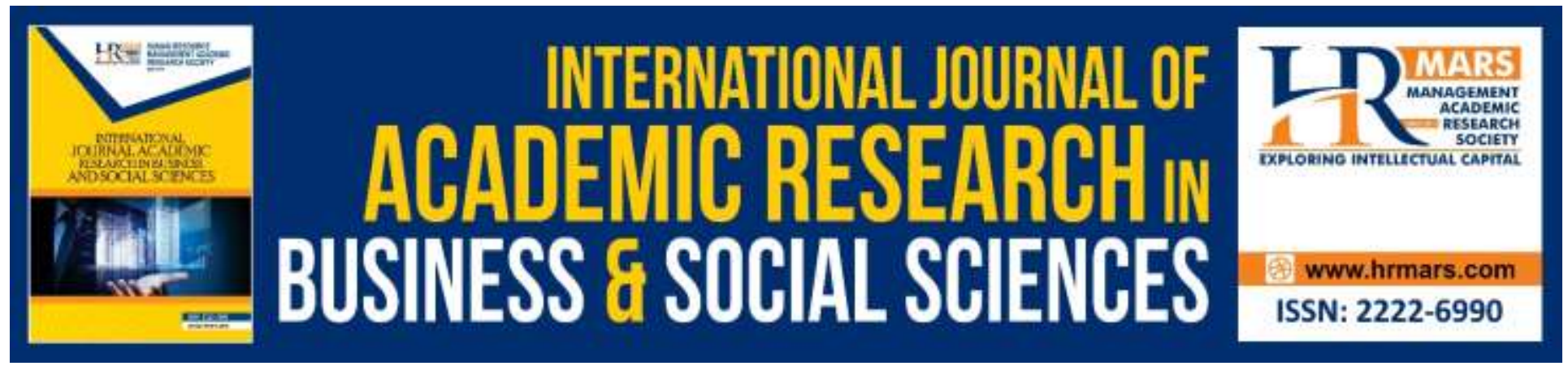

\title{
Reconstruction of Repentance Position in Islamic Criminal Law
}

\section{Muhammad Nur Aiman Bin Mohd Azhari, Wan Khairul Aiman Wan Mokhtar}

To Link this Article: http://dx.doi.org/10.6007/IJARBSS/v9-i11/6583

DOI: 10.6007/IJARBSS/v9-i11/6583

Received: 11 October 2019, Revised: 29 October 2019, Accepted: 07 November 2019

Published Online: 27 November 2019

In-Text Citation: (Azhari \& Mokhtar, 2019)

To Cite this Article: Azhari, M. N. A. B. M., Mokhtar, W. K. A. W. (2019). Reconstruction of Repentance Position in Islamic Criminal Law. International Journal of Academic Research in Business and Social Sciences, 9(11), 623632.

Copyright: (C) 2019 The Author(s)

Published by Human Resource Management Academic Research Society (www.hrmars.com)

This article is published under the Creative Commons Attribution (CC BY 4.0) license. Anyone may reproduce, distribute, translate and create derivative works of this article (for both commercial and non-commercial purposes), subject to full attribution to the original publication and authors. The full terms of this license may be seen

at: http://creativecommons.org/licences/by/4.0/legalcode

Vol. 9, No. 11, 2019, Pg. 623 - 632

http://hrmars.com/index.php/pages/detail/IJARBSS

JOURNAL HOMEPAGE

Full Terms \& Conditions of access and use can be found at http://hrmars.com/index.php/pages/detail/publication-ethics 


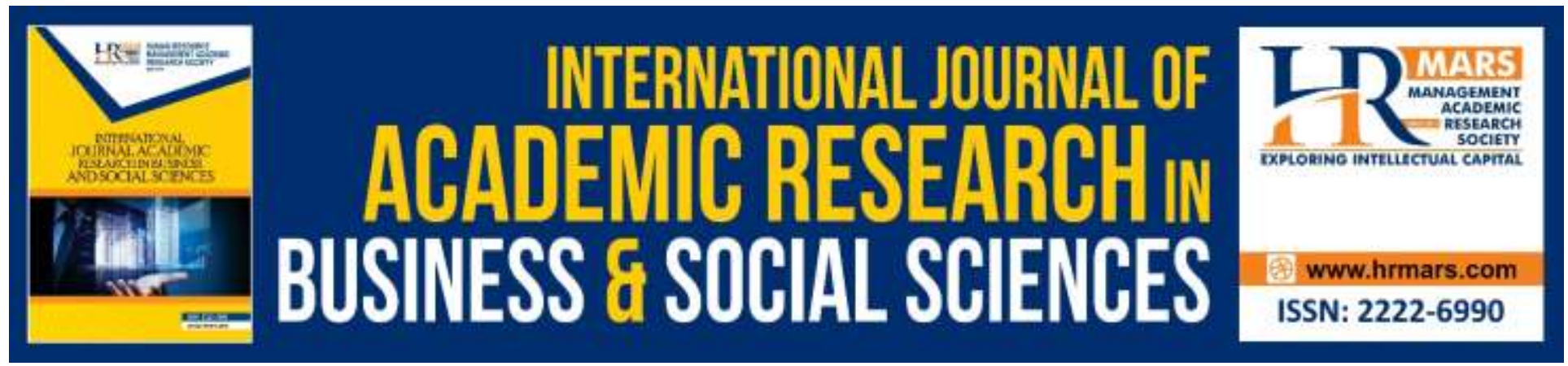

\title{
Reconstruction of Repentance Position in Islamic Criminal Law
}

\author{
Muhammad Nur Aiman Bin Mohd Azhari, Wan Khairul Aiman \\ Wan Mokhtar
}

Universiti Sultan Zainal Abidin (UniSZA), Gong Badak Campus, 21300, Kuala Nerus, Terengganu, Malaysia

\begin{abstract}
Reconstruction of the Position of Repentance in Islamic Criminal Law. Repentance is found in almost all categories and forms of crime with a variety of opinions about their influence on the criminal form that has already taken place determined. The contrast here is that repentance is an area with more vertical dimensions (divine) rather than horizontal (human). Placement of repentance as influencing punishment means to juxtapose two things that are different dimensions that are less commensurate. This is because repentance is not measurable, while the punishment for an offense must be very measurable. However, the Quran and hadith contain many doctrines about this conversion. This article examines the construct of repentance in the understanding of scholars and alternative position of repentance in Islamic criminal law. Based on research on hadith books and fiqh jinayah, it was found that basically all forms of crime, transgression, and sin had sanctions, both worldly and ukhrawi which must be treated. The study of the verses of the Koran and hadith shows that repentance remains a very individual area; he will not influence punishment except if someone's actions have touched the interests of the community.
\end{abstract}

Keyword: Reconstruction, Islamic Criminal Law, Repentance, Sanctions, Sin

\section{Introduction}

This article wants to find a position of repentance (istitâbah) in Islamic criminal law. This motivated by the existence of repentance in almost all categories (hudud, kisas, and takzir) and other forms of evil (jarîmah) in Islam. However, all scholars differ in their position the effect of this repentance on criminal form which has been specified. Abu Hanifah tends to in the opinion that repentance can abolishing the penalty for all criminal acts relating to the rights of Allah (haqq Allâh), while Imam Shafi'i and Malik stated that repentance does not erase all sentences. Among the things agreed upon by the scholars is on hirâbah crime (robbery accompanied murder, rape, 
and chaos), repentance of the offender before being arrested can delete all penalties imposed for the crime. This is based on QS. al-Maidah (5): 34. Problems that arise here, isn't the hirābah criminal offense, other than related to the rights of God (haqq Allah) (chaos security) that can be forgiven directly, too related to the rights of servants / humans (haqq al-'ibâd) (taking assets and killing) that does not can be forgiven before that right is fulfilled? If repentance removes punishment, what about it with human rights to property taken the offender? Similar things also occur in theft; in fiqh it is categorized as offense hudud (haqq Allah). Return of stolen property by thieves to their owners, can be understood as a form of repentance, does not result the death of this crime.

In other words, from a methodological side, categorizing criminal acts into haqq Allah and haqq al- ibâd is also still a problem. Important note here, 'Abdul Qadir 'Awdah states that there is no pure right of God (haqq Allah) or individual pure rights (haqq al 'ibâd), because all mukallaf's actions must contain both such rights. If so, the position of repentance in condemnation becomes increasingly blurred.

God indeed states that punishment is a sinner (QS. 5:34 \& 42:30). That is, punishment is a form of repentance. In some cases, the Prophet Muhammad also stated that punishment in the world would be removing punishment in the hereafter and becoming cleanser of the sins of the offender. For example, inside the application of stoning penalties to several adulterers (Maiz bin Malik, Juhainah woman) and Ghamidiah) in his time, the Prophet Muhammad stated that the sentence was the form of repentance of the offender for his sins.

\section{Literature Review}

Throughout the research that has been done, actually quite a lot of writing was found about repentance, but it can be said entirely in tasawuf. In the field this, repentance is one among some maqam achievement in business soul purification to perfection. Imam al-Ghazali in Ihya Ulûm adDîn said there are 9 kinds of maqam, namely repentance, zuhud, patience, ignorance, humility, bondage, willingness, love, and makrifat. Abu Nasr as-Sarraj at-Tusi in al-Lumâ' say there are 7 kinds of maqam, while al-Qusyariri states there are 6 kinds maqam. This whole tasawuf study puts repentance as the first maqam; become a base for other maqams.

Penance itself comes from the verb tâba, yatūbu, which means refer or return. According to ulama, repentance is cleansing the heart from all sin. Imam Haramain (Abu al-Ma ali al-Juwaini) said the repentance was leaving the desire to commit a crime he never did for raising God and abstain from his wrath. In The Holy Quran orders every believer to repent (QS 24:31 and 66:8). From this explanation it appears that repentance are in the personal domain and are more likely becomes an act that does not appear to be physical because it is done by the heart. The goal is self cleansing from sin. The form of repentance will more visible if it is associated with criminal law Islam. In this realm, repentance is put in the criminal responsibility of God (vertical) in addition to humans or to Country (horizontal). Accountability this is vertical which makes Islamic law is bidimensional (double dimension). 
Tahir Azhary points out, among the features the most prominent characteristic of Islamic law is its bidimensional nature (multiple dimensions or twin) namely the dimensions of the world and ukhrawi. The earthly / human dimension is intended for human welfare during life in this world.

\section{Research Methodology}

This study is a qualitative studywhich is a literature review and focus of the study in the form of reconstruction of repentance in law Islamic criminal law. Moving from the study, researchers using a philosophical approach to science, for mapping the existence of repentance in Jurisprudence and the possibility of reconstructing its existence, thereby the relationship of repentance and punishment looks harmonious according to scientific principles. The primary material in the study was books of hadith and jihayah Islamic criminal / criminal. The main hadith books used are nine major hadiths are al-Jâmi 'ash-Shhahîh (Sahih Bukhari), Shahîh Muslim bi Syarh an-Nawawî, Sunan Abî Dâwud, al-Jâmi 'ash-Shahîh wa Huwa Sunan at-Tirmidzî, Sunan anNasa'î, Sunan Ibn Mâjah, al-Musnad, al-Muwaththa ', and Sunan ad-Dârimî. The main jinayah jurisprudence book used is the 'Abdul Qadir 'Audah, 9 and part of a complete figh book that is Fiqh as-Sunnah by Sayyid Sabiq.10 Methods of data analysis to be used in this study is a descriptive analysis method. The main analytical tool here is epistemology the existence of repentance and its relationship with punishment. This is used to measure validity scientific principles of placement of repentance as part of or affect the shape punishment in jinayat fiqh. Next, with the same tool will be sought for reconstruction the existence of repentance in Islamic criminal law. The analysis process will be seen mapping the postulate and the initial building of repentance and the design of new forms based on philosophical principles of science (Mokhtar, 2017; Muthoka, Oluoch, Muiruri, 2018; Dimasi \& Theologou, 2018).

\section{Findings and Research Discussion}

\section{Penance in the Qur'an and Hadith in the Quran}

The word repentance is shared with all derivatives there are more than 80 (eight twenty) fruit. If the material is the verses classified, there are several important things complied with criminal law, namely:

1. Among the attributes of God is at-tawwâb (Recipient of Reconciliation). In the Quran, the form of at-tawwâb is followed by the word ar-rahîm found at 6 (six) places: (QS 2:37, 54, 128, 160 and 9:104 \& 118); also found in form without alîf lâm ma'rifah (tawwâb) accompanying with rahim (QS 4:64 and 49:12); and no along with other words (QS 110: 3). In a form of statement that God accepts repentance of his people is found in 14 other verses.

2. Among the important Islamic teachings are repentance. For this important position, Mushaf The Qur'an contains the word repentance as one name for the letter is at-Taubah letter (9th letter). Many verses of the Qoran encourage people to repent from wrongdoing that has been done Surah 5:74; 9: 3; 11:3, 52, 61, 90; 13:30; and 24:31). Prophet Moses once repented (QS 7:143) and teach repentance to his people (QS 2:54). Likewise his predecessor, Prophet Adam, once committed repentance because of 
violating God's prohibitions (QS 2:37). Other prophets also carried out this repentance procession (QS 9:117). Penance of the Prophet Muhammad and His followers are mentioned in QS. 9: 117.

3. If categorization of actions is used criminal (jarîmah) to hudud, kisas, and takzir, all get a place to go through the process of repentance. In the general form, The Quran speaks of evil (sû'an) (QS 6:54), as-sayyi'ât (QS 4:18), and fatanû (trials; torture, catastrophe, murder) (QS 85:10), and the evil of the idolaters (QS 9:5). For hudud, the Qur'an provides an example theft (QS 5:39) and hiraa (disturbance security / robbery accompanied by murder) and to be considered murder (QS 5:71). For example, the takhir of takzir is presented quite a lot, the liver almost turned away from faith (QS 9: 117), do not give charity to the Apostle when asking for advice (QS 58:13), do not go to war (QS 9:118), opening or displaying aurat (QS 24:31), mocking (QS 49:11), insulting, looking for people's faults, and gossiping (QS 49:12), intercourse during menstruation (QS 22:222), and indecent acts (QS 4:16).

\section{Repentance in Islamic Literature}

In the treasure of Islamic literature, more repentance many are discussed in the realm of morality and tasawuf than in the field of faith and sharia / law. Important works about this repentance for example can be found in Ihya Ulûm ad-Dîn works Al-Ghazali (1058-111M), 11 Risalah alQusyayriyyah al-Qusyairi's work (986 M / 376 H-1074 M / 465 H), 12 at-Tawwâbîn by lbn Qudamah (1147 M / 541 H / 1223 M / 620 H), 13 al-Futuhât al-Makkiyah works Ibnu 'Arabi (1165 / 560-1240 M / 638 H), 14 and al-Âdab asy-Syar'iyyah Ibnu Muflih (w. 763 H).

In Ihya Ulûm ad-Dîn repentance is peeled on the end of juz 11 until the beginning of juz 12. AlGhazali started the discussion of the fact repentance, then repentance obligations, conditions repentance is accepted, the benefits of repentance, and all kinds the act of sin that desires repentance. According to Al-Ghazali, a number of hadiths and atsar not counting, as well as the existence of ijmak, showing conversion must be done continuously and in every case. Reasons Al Ghazali about this continuity, that every human being never been detached from evil deeds with his limbs. Even the prophets it is mentioned that the Quran is not free from the vice.

Al-Ghazali based his opinion on this the statement of the Prophet who always had 70 times every night. God Himself states that He forgives the Prophet for his sin the past and the future (QS 48: 2).

Al-Ghazali also invokes examples of compulsory deeds, for example killing, theft, eating the property of the child orphans, testimonies and false oaths, eating riba, drinking khamar, każaf, fleeing from war, and disobedient to parents.

Remorse (an-nadam) as a soul of repentance as Al Ghazali's statement, referred to by Ibn 'Arabi and al-Qusyairi as the main pillar repentance, like the position of wukuf in Arafah as the largest pillar of the pilgrimage. Al-Qusyairi and Ibn 'Arabi then specifies the terms of acceptance of repentance and the forms of reconciliation. At-Tawwâbîn Ibn Qudamah is the only one a book that talks specifically about repentance. However, this book does not address repentance in 
theoretical or normative form. Here Ibn Qudamah presents many stories about those who repent.

Furthermore from the above works, repentance is a core of the teachings of tasawuf. Penalty is a maqam (station) that must be passed a sufi to achieve perfection self - esteem search and proximity to his God. Al-Qusyairi said that repentance is the first terminal to be taken by a salik, the first maqam of thâlibîn (knowledge seekers). Harun Nasution states that the repentance meant by the Sufi is the actual repentance, the repentance will not leads to sin again. Sometimes repentance it was not achieved by one time; process repentance is done up to seventy times. "Penalty the truth in sufism is to forget about everything except God. People who repent, say Hujwiri, is a person who loves God. People who love God always holds contemplation about God."

\section{Constructs of Repentance in Islamic Criminal Law}

In the realm of jurisprudence, repentance is not discussed in particular. There are no chapters, not even chapters, which describes repentance. Material about repentance spreads in several parts of fiqh material. In the Fiqh as-Sunnah by Sayyid Sabiq for example, repentance is found in part (1) of marriage and adultery; (2) the initial part of hudud; (3) qażaf (accusing adultery); (4) apostasy, and (5) hirâbah (security / robbery). Discussion the most about repentance is found in the problem of hirâbah and apostate. This is because of this section there is a special passage emphasizing there is repentance, then the interpretation appears diverse.

The main reason for repentance in the hirâbah is QS al-Maidah (5): 33-34:

"Verily the retaliation against those who fight Allah and His Messenger and make damage on the face of the earth, only they are killed or crucified, or cut their hands and feet with reciprocated, or disposed of from the country (place his residence). That is a humiliation for them in the world, and in the hereafter they suffered great torment, except those who repented (before them) you can master (capture) them; then know that Allah is Forgiving the Most Merciful."

Different opinions about repentance hirâbah is quite extensive. Ibn Rusyd in Bidâyat al-Mujtahid explained that there were four opinions:

1) Repentance only aborts punishment hirâbah, while all the rights of God besides and the rights of (human) servants are still demanded (not deleted because of repentance). Opinion this is held by Imam Malik.

2) Repentance aborts the hirâbah sentence and all other offenses categorized to the right of God that accompanies hirâbah that is adultery / rape, drinking khamar, and theft. Whereas rights humans, namely property and life do not fall because of repentance unless the guardian forgives.

3) Repentance takes away all the rights of God, while related to murder and property continue to be prosecuted if the goods taken on hirābah time still exists. 
4) Repentance aborts all rights humans in the form of murder and property, except the treasure can still be found. Sayyid Sabiq chose the second opinion because in his opinion the fairest. Provisions for death punishment for the offender for repenting before he is captured and controlled "is an indication of inner enlightenment and commitment to open a new, clean life, far from subversive and hostile actions against Allah and His Messenger." As for rights humans do not fall; still sued with kisas or with a return on property. If the offender committing a crime of murder and retrieval of assets, death penalty crucifixion; what applies is kisas. If the offender takes assets, then the sanction of the hand cut will fall; what applies is the seizure of property.

Likewise repentance in apostasy; various opinions of scholars because of the arguments there is that possible. Even though Allah is Almighty states that people are looking for religion besides Islam, in the hereafter including those who lose (QS 5:85) and the curse of Allah, the angels and humans are all inflicted to them (QS 5:87), but people those who repent, after the infidel and make reparation will be given forgiveness (QS 5:89).

Indeed, there are traditions that are so strict states: "Who changes his religion, let you kill him" (Narrated by Jamaah, except Muslims), but there are other traditions states that there must be a process of inviting the perpetrator repents first. Daruquthni and Baihaqi narrated from Jabir, a woman named Ummu Marwan left Islam. Prophet ordered the friends to invite him back to Islam. If he repents, he returns become a Muslim, while if he refuses, he is subject to death penalty. Umm Marwan refused to return embraced Islam so that it was subject to the death penalty. Prophet also said to Muaz when sending him to the land of Yemen, "If you get a man whoever is an apostate from Islam, then brings he is to return to Islam. If he returns, keep it up. But if he refuses, then kill he. And if you get that woman even the apostate from the Islamic religion, ask him for it back to Islam. If he's back, stay tuned. But if he refuses, kill him."

So, even the punishment for apostates is a death sentence, but only after the perpetrators are asked to repent and return to Islam. Here the position of conversion is important because be determining whether dead execution can be implemented or not.

Referring to Fiqh as-Sunnah, the material of repentance in the chapter of Marriage and conspiracy organized by the perpetrators to commit repentance; beg for forgiveness of sins that has been done, regretted and determined not repeating the act, as well as directing to the deeds good. In this way, God will please accept the repentance of the perpetrator and will enter the perpetrators into the ranks of those who His blessed (QS 25: 68-70).

While the conversion at the beginning of hudud contains an explanation of the relationship between the sentence (limit) with the abolition of sin. In short it can mentioned, most scholars believe that if the penalty sentence is executed on the perpetrators of crime, it will wipe out the sins they have committed and will not be tortured again in the hereafter. This is based on Bukhari and Muslim:

"Whoever breaks the promise, however God covers his mistake (unknown other people), then his affairs are up to God; if He desires it will be forgiven, but if He desires it will He tortures (in the hereafter)." 
The study of repentance in the qażaf chapter contains description of the relationship between repentance and acceptance against the perpetrator's testimony for other cases which he will face after the case of the solution is resolved. Not much Sayyid Sabiq's explanation of this problem. It is only referring to the Mughirah case charged with adultery by Syabal bin Ma'bad, Nafi' bin Haris bin Kaldah, and Abu Bakrah. Syabal and Nafi' admitted his lie, while Abu Bakrah refused to say lying. Because that, Umar did not accept his testimony (for subsequent cases). Tukimin, Yusoff, Baharudin, \& Hussain, 2018

Among the specific fiqh books that contain jurisprudence / the criminal is al-Tasyrî' al-Jin'î alIslami. This book considered to be able to describe legal portraits Islamic criminal law in a complete and systematic manner; written by Abdul Qadir Audah, a judge, expert law, mujahid, and da'i. Like Sayyid Sabiq in the Figh as-Sunnah, Abdul Qadir is already inside this book also contains repentance material spread in five chapters: (1) attempted crimes (no finished because of repentance); (2) cancellation of penalties, including the repentance of the perpetrators; (3) qażaf (accusing adultery), namely the testimony of the perpetrator qażaf after repenting; (4) hirâbah (interference security), namely the discussion of repentance of people who sentenced to hudud other than muhârib; and (5) apostasy, which is about repentance of the offender.

If Fiqh as-Sunnah and at-Tasyrî' al-Jinâ'î allslâmî are compared, there is a common focus discussion of repentance which is on qażaf, apostasy, and hirâbah. The difference, Fiqh as-Sunnah too presenting repentance to the marriage chapter and adultery; in the work of Abdul Qadir this was not found. While the study in Figh as-Sunnah which breaks down a little repentance on the early part of hudud can be juxtaposed with al-Tasyrî' al-Jin'î al-Islâmî which discusses it in chapter on attempted criminal offenses and cancellations punishment. This is because both contain about the effect of repentance on punishment criminal act.

It can be concluded that material is repentance in jinayat fiqh spreads in various chapters, according to need. However, there are three points of concentration, namely in qażaf, apostasy, and hirâbah. This guess is strong because in these three problems there is a special proposition which associates it with repentance. On other hudud problems, such as adultery and theft, repentance is not the focus attention, but the hadiths about the problem It is also much related to repentance.

\section{Conclusion}

Like all aspects of Islamic law, at essentially all forms of crime / violations / sin has sanctions, both worldly and ukhrawi and therefore must be treated. This too related to the purpose of punishment in Islam namely the salvation of the people, both the world and the hereafter, personal and community.

Study of the verses of the Koran and Hadith indicates that repentance remains being a region that is very individual in nature; he will not influence punishment except if someone's deeds have touched the interests of other people and individuals. The exception to this is the hirâbah delicacy not related to harm to others because the verse about this is so clearly stated that the repentance of the offender before being arrested can remove punishment. However, for this 
case there are still more opportunities for discussion continued, because it was very difficult to imagine delights

Hirâbah without the element of disrupting interests general - for example in the long term and personal interests.

Among the important things are examined further from the law of repentance is the category of haqq Allah and haqq al-'ibâd / haqq al-insan. In Islamic criminal law literature, this category still haven't got a place and an explanation adequate. This needs to be developed, for example to general and personal interest categories.

\section{Acknowledgement}

This paper is founded on the research project of the Fundamental Research Grant Scheme FRGS/1/2018/SSI03/UNISZA/02/2 (Project No: RR279). Special appreciation is owed to Ministry of Higher Education Malaysia (MOHE) and Universiti Sultan Zainal Abidin (UniSZA) for sponsoring and supporting this research.

\section{Corresponding Author}

Wan Khairul Aiman bin Wan Mokhtar (Ph.D), Senior Lecturer, Universiti Sultan Zainal Abidin (UniSZA), Gong Badak Campus, 21300 Kuala Nerus.

E-mail:wk_aiman@yahoo.com / wkhairulaiman@unisza.edu.my

\section{References}

'Awdah, 'Abd al-Qâdir. (1994). al-Tasyrî' al-Jinâ'î al-Islâmî, juz I dan II. Beirut: Mu'assasah alRisâlah. Ctk: XII.

Abu-Daud. (1997). Sunan Abî Dâwud. Beirut: Dar Ibn Hazmen.

Al-'Awwa, M. S. (1983). Fî Ushûl an-Nizhâm al-Jinâ'î al-Islâmi. Cairo: Dâr al-Ma'rif.

Al-Bukhari. (n.d.). al-Jâmi' ash-Shâhih. Cairo: al-Matba'ah as-Salafiyyah.

Al-Darimi. (2000). Sunan ad-Dârimî, juz I. Riyadh: Dar al-Mughni li an-Nasyr wa at-Tawzi.

Al-Mawardi. (2006). al-Ahkâm ash-Shulthâniyyah wa al-Wilâyah al-Dîniyyah, in-tahqiq by Ahmad Jâd. Cairo: Dâr al-Hadîth.

Al-Nasa'i. (n.d.). Sunan an-Nasâ'î, ta'liq by Muhammad Nasiruddin al-Albani. Riyadh: Maktabah al-Ma'arif li an-Nasyr wa Tawzi'. Ctk: I.

Al-Nawawi. (1929). Shahîh Muslim bi Syarh an-Nawawî. Cairo: Matba'ah al-Misriyyah.

Al-Tirmizi. (1968). al-Jâmi' ash-Shâhih wa Huwa Sunan at-Tirmizîi, is idle by Ahmad Muhammad Syakir, Muhammad Fuad Abdul Baqi, and Ibrahim Utwah Awd. Egypt: Mustafa al-Babi alHalabi wa Syurakahu. Ctk: II.

Azhary, M. T. (2004). Legal State (2nd ed.). Jakarta: Kencana.

Dimasi, M. \& Theologou, S. (2018). Multiliteracy Approaches to Foreign Language Teaching: The Use of Web Tools. Multilingual Academic Journal of Education and Social Sciences, 6(1), 126-147 (in Greek).

Hanbal, A. (2006). al-Musnad, in Software al-Maktabah Syamilah, (Isdar version 3.15). 
Ibn-Majah. (n.d.). Sunan Ibn Mâjah, in-tahqiq by Muhammad Fuad Abdul Baqi. Dar al-Ihya' al-Kutub al-'Arabiyyah.

Malik. (1997). al-Muwaththa' riwayat Yahya bin Yahya al-Laysi al-Andalusi. Beirut: Dar al-Gharbi al-Islami. Ctk: II.

Mokhtar, W. K. A. W. (2017). Concept Al-Hadīth Al-Mawḍūiy as a Method of Collecting and Analyzing Research's Data. International Journal of Academic Research in Business and Social Sciences, 7(2), 2222-6990.

Muthoka, N. I., Oluoch, O., Muiruri, P. M. (2018). The Impact of Agency Banking Financial Innovation on Market Capitalization of Commercial Banks Listed in NSE, Kenya, International Journal of Academic Research in Accounting, Finance and Management Sciences 8 (4): 110-119.

Nasution, H. (1973). Philosophy and Mysticism in Islam. Jakarta: Bulan Bintang.

Qurthubi, A. A. (2006). al-Jâmi`li Ahkâm al Qur'ân. Beirut: Mu'assasah al-Rislah. Ctk: I.

Sayed, A. (1953). Tafsîr Âyât al-Ahkâm. Cairo: Mathba'ah Muhammad 'Alî Syubay' wa Awlâdih.

Shabuni, A. (1977). Rawâ'i' al-Bayân fí Tafsîr Âyât al-Ahkâm min al-Qur'ân. Damascus: Maktabah al-Ghazâlî.

Shidqi, A. (1987). al-Jarîmah wa al-'Uqûbah fí as-Syarî́ah al-Islâmiyyah. Cairo: Maktabah alNahdhah al-Mishriyyah.

Tukimin, R., Yusoff, N. M. R. N., Baharudin, H., \& Hussain, F. (2018). Innovative Arabic Language Teacher: A Dream or A Hope. International Journal of Academic Research in Progressive Education and Development, 7(4), 158-165

Wensinck, A. J. (1936). al-Mu'jam al-Mufahras li al-Fazh al-Hadîth an-Nabawî. Leiden: E.J. Brill. Zahrah, M. A. (n.d.). al-Jarîmah wa al-'Uqûbah fi al-Fiqh al-Islâmî. Cairo: Dâr al- Fikr al-'Arabî. 